\title{
ISOLASI DAN PENENTUAN KADAR FLAVONOID EKSTRAK ETANOLIK HERBA SAMBILOTO (Andrographis paniculata (BURM.F.) NESS)
}

\section{ISOLATION AND DETERMINATION OF FLAVONOID CONTENT OF (Andrographis paniculata (BURM.F.) NESS) ETHANOLIC HERB EXTRACT}

\author{
Ichwan Ridwan Rais \\ Fakultas Farmasi Universitas Ahmad Dahlan \\ Jl. Prof.Dr. Soepomo,Janturan, Yogyakarta, Telp. (0274) 379418 \\ Email:ichwanridwanrais@yahoo.co.id
}

\begin{abstract}
ABSTRAK
Sambiloto (Andrographis paniculata (Burm.f.) Ness) mengandung andrografolid, neoandrografolid, dan senyawa flavonoid yang telah diketahui apigenin-7,4'-di-O-metil eter, 5hidroksi7,8,2',3'tetrametoksiflavon, dihidroksi-dimetoksiflavon. Flavonoid berpotensi sebagai antioksidan dan mempunyai aktivitas sebagai anti bakteri, anti inflamasi, anti alergi dan anti thrombosis. Struktur kimia obat dapat menjelaskan sifat obat dan keterkaitan unit struktur dan molekul obat dengan aktivitas biologinya. Senyawa dengan gugus fungsi yang sama dapat memberikan respon biologis yang sama karena bekerja pada reseptor yang sama. Telah dilakukan penentuan kandungan flavonoid total ekstrak etanol sambiloto menggunakan metode Chang, identifikasi menggunakan metode spektrofotometri. Hasil pengukuran menunjukkan kandungan flavonoid total ekstrak etanol sambiloto sebesar $46,322 \mathrm{~g} / \mathrm{kg}$.
\end{abstract}

Kata kunci: Flavonoid, Andrographis paniculata.

\begin{abstract}
(Andrographis paniculata ( Burm.f. ) Ness ) is containing andrografolid, neoandrografolid, and flavonoids known as apigenin-7,4'-di-O-methyl ether, 5-hydroxy7,8,2',3'tetrametoxyflavon, dihydroxy-dimetoxyflavon. Flavonoids as antioxidants, have potential as an anti-bacterial activity, anti-inflammatory, anti-allergic and anti-thrombosis. The chemical structure of the drug may explain the nature of the drug and linkage units and structures of drug molecules with biological activity. Compounds with the same functional groups can provide the same biological response due to work on the same receptors. This present study is determine the total flavonoid content of the ethanol extract of A. paniculata use Chang method, identification using spectrophotometric method. The measurement results showed that total flavonoid content of the ethanol extract of A. paniculata amounted to 46.322 $\mathrm{g} / \mathrm{kg}$.
\end{abstract}

Keywords: Flavonoid, Andrographis paniculata.

\section{PENDAHULUAN}

Sambiloto Andrographis paniculata (Burm.f.) Ness) merupakan tumbuhan asli Indonesia yang banyak digunakan secara tradisional sebagai obat penurun panas, peluruh air seni, influenza, disentri basiler, radang amandel, radang paru-paru, radang ginjal, obat gatal, luka karena infeksi, abses dan kudis (Sudarsono et al., 2006). 
Herba dan percabangannya mengandung andrografolid, neoandrografolid, homoandrografolid, 14-deoksi-11,12didehidroandrografolid, 14-deoksi-11-oksoandrografolid, 14-deoksiandrografolid, andrografin, panikulid A, B dan C, panikulin (Chao dan Lin, 2010). Selain itu, A. paniculata juga mengandung senyawa flavonoid (Sudarsono dkk., 2006).

Flavonoid merupakan senyawa metabolit sekunder yang terbentuk melalui jalur sikimat. Senyawa ini diproduksi dari unit sinnamoil-CoA dengan perpanjangan rantai menggunakan 3 malonil-CoA. Enzim khalkon synthase mengabungkan senyawa ini menjadi khalkon. Khalkon adalah prekursor turunan flavonoid pada banyak tanaman (Dewick, 2002).

Struktur kimia obat dapat menjelaskan sifat obat dan keterkaitan unit struktur dan molekul obat dengan aktivitas biologinya. Senyawa dengan gugus fungsi yang sama dapat memberikan respon biologis yang sama karena bekerja pada reseptor yang sama atau mempengaruhi proses biokimia yang sama pula (Siswandono, 2000). Guerrero et al. (2012) membuktikan dalam penelitian hubungan struktur-aktivitas bahwa kombinasi pada rangka flavonoid dapat meningkatkan aktivitas penghambatan Angiotensin-Converting Enzyme.

Flavonoid berpotensi sebagai antioksidan dan mempunyai aktivitas sebagai anti bakteri, anti inflamasi, anti alergi dan anti thrombosis (Lipinski, 2011). Flavonoid terutama berupa senyawa yang larut dalam air yang dapat diekstraksi dengan etanol $70 \%$ dan tetap ada dalam pelarut tersebut setelah difraksinasi dengan pelarut non polar. Flavonoid merupakan senyawa fenol yang dapat berubah warna bila ditambah basa atau ammonia sehingga mudah dideteksi pada kromatogram atau dalam larutan. Flavonoid mengandung gugus aromatis terkonjugasi yang menunjukkan serapan yang kuat pada spektrofotometri (Harborne, 1996).

Kandungan flavonoid dalam tanaman sambiloto berpotensi sebagai antioksidan yang terkait dengan beberapa aktivitas seperti antiinflamasi dan antibakteri. Potensi ini didukung dengan kemudahan isolasi dan penentuan kadar flavonoid menggunakan metode kromatografi. Penelitian flavonoid sebagai pengobatan dengan menggunakan bahan alam telah menjadi focus penelitian para ilmuan, karena itu perlu dilakukan penelitian kandungan flavonoid dalam tumbuhan sambiloto.

\section{METODE PENELITIAN}

\section{Bahan Penelitian}

Bagian tanaman yang digunakan adalah herbanya yang diperoleh dari Desa Girimulyo, Kecamatan Nanggulan, Kabupaten Kulon progo. Identifikasi tanaman dilakukan di Laboratorium Farmakognosi, Bagian Biologi Farmasi, Fakultas Farmasi, Universitas Gadjah Mada. Bahan yang digunakan adalah standar quersetin (Sigma), etanol, n-heksan, n-butanol, asam asetat. Standar quersetin digunakan sebagai pembanding kesetaraan kandungan aglikon flavonoid dalam ekstrak sambiloto.

\section{Jalannya Penelitian}

\section{Ekstraksi herba sambiloto menggunakan pelarut etanol}

Serbuk herba sambiloto sebanyak 100 gram diekstraksi menggunakan alat Soxhlet dengan cara membungkus serbuk herba dalam selongsong kertas saring dan dimasukkan ke dalam bagian rumah siput dari alat Soxhlet kemudian ditambahkan cairan penyari yang yang digunakan dengan polaritas yang berbeda sebanyak dua kali sirkulasi. Alat Soxhlet kemudian diletakkan di atas pemanas dan dihubungkan dengan pendingin yang dialiri air pada bagian atas. Proses penyarian dengan alat Soxhlet dilakukan hingga cairan penyari yang merendam selongsong berisi serbuk dalam sifon terlihat bening tidak berwarna. Hasil penyarian pada labu alas bulat ditampung.

\section{Isolasi flavonoid ekstrak etanolik sambiloto}

Filtrat hasil ekstraksi dihidrolisis menggunakan $\mathrm{HCl} 2 \mathrm{~N}$ dengan perbandingan 1:1 kemudian direfluks selama 2 jam. Selanjutnya filtrat difraksinasi menggunakan etil asetat. 
Fraksi etil asetat diambil dan diuapkan hingga volume tertentu. Fraksi kemudian ditotolkan model pita pada fase diam kertas Whatman 1 dan dielusi dengan fase gerak asam asetat $15 \%$. Bercak kuning dengan Rf sama yang diuapi ammonia dikumpulkan dan diekstraksi dengan metanol. Filtrat dianalisis kandungan aglikon flavonoid secara spektrofotometri panjang gelombang $425 \mathrm{~nm}$ pembanding quersetin.

\section{Penentuan kandungan flavonoid menggunakan spektrofotometri}

Penentuan kandungan flavonoid menggunakan larutan seri kadar standar quersetin, optimasi panjang gelombang, penentuan absorbansi isolat flavonoid, dan kalibrasi hasil pengukuran. $100 \mathrm{mg}$ quersetin dilarutkan dalam metanol dalam labu takar 100 $\mathrm{ml}$ digojog sampai homogen. Dibuat larutan standar 5, 10, 20, $25 \mu \mathrm{g} / \mathrm{mL}$ dan ditambahkan zat pembuat kompleks warna $\mathrm{AlCl}_{3}$. Blanko metanol murni (Chang, et al, 2002).

\section{Analisis hasil}

Kandungan flavonoid ekstrak etanolik sambiloto ditentukan sebagai aglikon flavonoid menggunakan persamaan regresi linier kurva baku seri kadar versus absorbansi standar quersetin dengan memperhitungkan faktor pengenceran.

\section{HASIL DAN PEMBAHASAN}

Herba sambiloto yang telah dikeringkan kemudian diserbuk. Serbuk diekstraksi menggunakan alat Soxhlet dengan pelarut etanol $96 \%$ sampai cairan penyari yang merendam selongsong berisi serbuk dalam sifon terlihat bening tidak berwarna (Rais, 2012). Hasil diuapkan sampai diperoleh ekstrak kental.

Filtrat hasil ekstraksi yang dihidrolisis untuk memecah ikatan glikosida menggunakan $\mathrm{HCl} 2 \mathrm{~N}$ dengan perbandingan 1:1 kemudian direfluks selama 2 jam untuk mendapatkan flavonoid non polar yang bebas dari gugus gula. Selanjutnya filtrat difraksinasi menggunakan pelarut non polar etil asetat dan diuapkan hingga volume tertentu untuk meningkatkan konsentrasi flavonoid. Fraksi etil asetat yang ditotolkan model pita pada fase diam kertas Whatman 1 dan dielusi dengan fase gerak asam asetat $15 \%$ tidak dapat terelusi seperti terlihat pada Gambar 1.

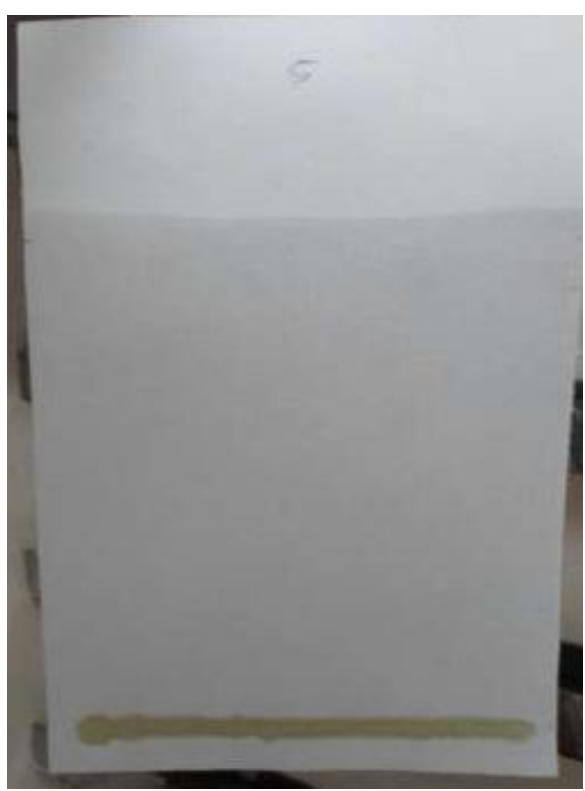

Gambar 1. Hasil elusi ekstrak etanol sambiloto menggunakan fase diam kertas Whatman dan fase gerak asam asetat $15 \%$, sampel tidak dapat terelusi.

Fase gerak kemudian diganti menggunakan Butanol-Asam asetat-air (BAA) dengan perbandingan 4-1-5 (Harborne, 1996) dan fase diam menggunakan silika gel $\mathrm{F}_{254}$. Hasil optimasi elusi memperlihatkan bercak kuning setelah diuapi ammonia pada sampel tidak terlihat jelas dan berekor sebagaimana terlihat pada Gambar 2.

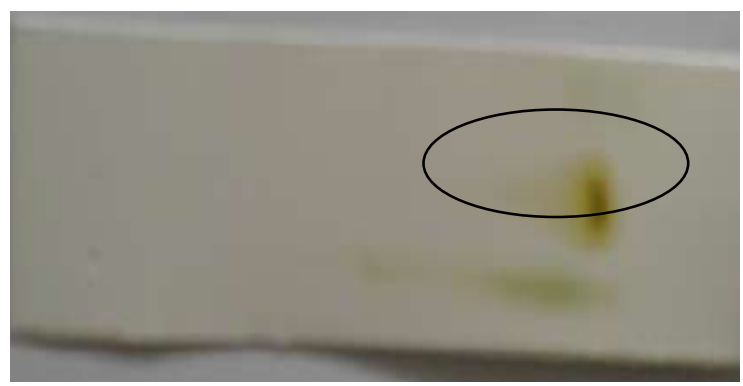

Gambar 2. Hasil elusi ekstrak etanol sambiloto menggunakan fase diam silika gel dan fase gerak BAA setelah diuapi ammonia, terlihat bercak kuning berekor dari flavonoid 
Proses optimasi elusi dan isolasi flavonoid yang belum optimal dilakukan paralel dengan penentuan flavonoid total langsung dari larutan ekstrak sambiloto dalam pelarut etanol menggunakan komplek $\mathrm{AlCl}_{3}$ tanpa proses isolasi. Penentuan menggunakan panjang gelombang hasil optimasi $402 \mathrm{~nm}$ dan pembanding standar quersetin dengan seri kadar $5,10,20,25 \mu \mathrm{g} / \mathrm{ml}$. Hasil pengukuran absorbansi visible seri kadar standar quersetin terlihat pada Tabel I.

\section{PEMBAHASAN}

Berdasarkan hasil pengukuran seri kadar standar quersetin, diperoleh persamaan $\mathrm{Y}=$ $0,034 \mathrm{X}+0,079$ dengan nilai $\mathrm{r}=0,9944$ seperti terlihat pada gambar 3 diatas.

Nilai flavonoid total sampel ekstrak etanol herba sambiloto diperoleh dengan memasukkan nilai absorbansi pada kurva standar kuersetin dengan persamaan $\mathrm{Y}=0,034 \mathrm{X}+0,079$, hasil rata-rata kadar flavonoid total dalam ekstrak etanolik sambiloto sebesar $46,322 \mathrm{~g} / \mathrm{kg}$ ekstrak atau $4,63 \%$ terhadap kuersetin. Kadar flavonoid ini lebih besar dibandingkan kadar flavonoid dalam ekstrak etanolik binahong sebesar 7,687 $\mathrm{mg} / \mathrm{kg}$ (Selawa, dkk, 2013) maupun dalam ekstrak etanolik daun buah merah sebesar 0,99\% (Desmiaty, dkk, 2009) dengan metode yang sama yaitu metode Chang (2002). Kandungan flavonoid ini berpotensi lebih baik dalam pengembangan tanaman herbal terkait aktivitasnya. Sambiloto memiliki lebih dari 10 macam flavonoid yang umumnya meliputi 5hidroksi-7,8-dimetoksiflavon, 5-hidroksi7,8,2',3'-tetrametoksiflavon, 5-hidroksi-7,8,2'trimetoksiflavon 7-O-metilwogonin dan 2'-metil eter (Chao and Lin, 2010). Flavonoid merupakan senyawa alam yang berpotensi sebagai antioksidan yang mampu menangkal radikal bebas yang berperan pada timbulnya penyakit degeneratif melalui mekanisme perusakan sistem imunitas tubuh, oksidasi lipid dan protein (Selawa et al. 2013). Herba sambiloto termasuk tanaman liar yang terbukti secara ilmiah memiliki banyak aktivitas farmakologi. Penentuan kandungan flavonoid dalam ekstrak sambiloto bermanfaat dalam penemuan pengobatan yang berkaitan dengan aksi radikal bebas yang berefek patologi.

Tabel I. Data hasil pengukuran seri kadar standar quersetin

\begin{tabular}{cc}
\hline Konsentrasi $(\boldsymbol{\mu g} / \mathbf{m l})$ & Absorbansi \\
\hline 5 & 0,259 \\
10 & 0,491 \\
20 & 0,761 \\
25 & 0,919 \\
\hline
\end{tabular}

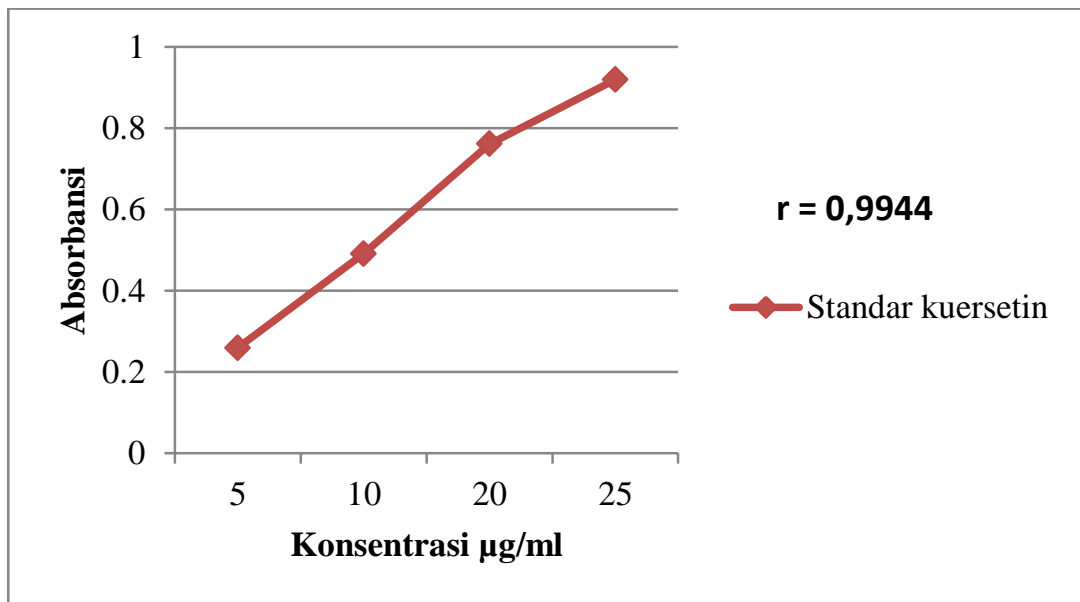

Gambar 3. Kurva seri kadar standar kuersetin, hubungan antara seri kadar quersetin dalam metanol versus nilai absorbansi 


\section{KESIMPULAN}

Ekstrak etanolik sambiloto mengandung flavonoid total dengan kadar 46,322 $\mathrm{g} / \mathrm{kg}$ $(4,63 \%)$ terhadap quersetin dalam ekstrak.

\section{UCAPAN TERIMAKASIH}

Penelitian ini dibiayai oleh Lembaga Penelitian dan Pengembangan Universitas Ahmad Dahlan tahun anggaran 2013.

\section{DAFTAR PUSTAKA}

Agarwal, R., Sulaiman, S.A., Mohamed, M., 2005, Open Label Clinical Trial to Study Adverse effect and Tolerance to Dry Powder of the Aeral Part of Andrographis paniculata in Patient Type 2 with DM, Malay. J.of Med. Sci. 12(1): 13-19.

Akbar, S. 2011, Andrographis paniculata: A Review of Pharmacological Activities and Clinical Effects, Journal of AMR,16(1):66-77.

Berdanier, C.D., Dwyer, J., Feldman, E.B., 2006, Handbook of Nutrition and Food, $2^{\text {nd }}$ edition, CRC Press.

Chang, C.C., Yang., M.H., Wem, H.M., Chern, J.C., 2002, Estimation of Total Flavonoid Content in Propolis by Two Comlpementary Colorimetric Methods, Journal of Food and Drug Analysis, Vol. 10, No.3, 2002. Pages 178-182.

Chao, W.W. and Lin, B.F., 2010, Isolation and Identification of Bioactive Compounds in Andrographis paniculata (Chuanxinlian), Chinese Medicine Journal. 5:1-15.

Chaves, J.S., DaCosta, F.B., de Frietas, L.A.F., 2009, Development of Enteric Coated Tablet From Spray Dried Extract of Fewerfew (Tanacetum parthenium L.), Braz. J. Phar.Sci. 45(3): 573-84.

Dandu, A.M., dan Inamdar, N.M., 2009, Evaluation of beneficial effectsof antioxidant properties of aqueous leaf extract of Andrographis paniculata in STZ-induced diabetes. J.Pharm Sci.22(1):49-52.

Depkes RI, 1986, Sediaan Galenik, Departemen Kesehatan RI, Jakarta.

Desmiaty, Y., Ratnawati, J., Andini, P., 2009, Penentuan Jumlah Flavonoid Total Ekstrak Etanol Daun Buah Merah (Pandanus conoideus Lamk.) Secara Kolorimetri Komplementer, Seminar Nasional POKJANAS TOI XXVI, Universitas Jendral Achmad Yani.

Dewick, P.P., 2002, Medicinal Natural Products, A Biosynthetic Approach, John Wiley and Sons, Ltd., School of Pharmaceutical Sciences University of Nottingham, UK. P.149

Guerrero, L., Castilo, J., Quinones, M., GarciaValve, S., Arolla, L., Pujadas, G., Muguerza, B., 2012, Inhibition of Angiotensin-Converting Enzyme Activity By Flavonoids: StructureActivity Relationship Studies, Plos One, 7(11): 49493.

Harborne, J.B., 1996, Metode Fitokimia, Penuntun Cara Modern Menganalisis Tumbuhan, Edisi kedua, diterjemahkan oleh Kosasih Padmawinata dan Iwang Soediro, Penerbit ITB, Bandung

Katzung, B.G., 2002, Farmakologi Dasar dan Klinik, Terjemahan Bagian Farmakologi Fakultas Kedokteran Universitas Airlangga, Salemba Medika, p.694-709

Lipinski, B. 2011, Hydroxyl Radical and Its Scavengers in Health and Disease, Review Article, Oxidative Medicine and Cellular Longevity, 11:1-9.

Li, W., Dai, R.J., Yu, Y.H., Li, L., Wu, C.M., Luan, W.W., et al., 2007, Antihyperglicemic Effect of Cephalotaxus sinensis Leaves and GLUT4 Translocation Facilitating Activity of Its Flavonoid Constituens, Biol. Pharm. Bull. 30(6).1123-1129. 
List, P,H., and Schmidt, P.C., 1989, Phytopharmaceutical Technology, Florida, CRC Press. P53-56.

Mulja, M., dan Suharman, 1995, Analisis Instrumental, Airlangga Univ. Press., Surabaya, hal 224.

Niranjan, A., Tewari, S.K., Lehry, A., 2010, Biological Activities of Kalmegh (A. Paniculata Ness) and Its Active Principles, Indian J. of Nat. Prod. And Res. 1(2): 125-135.

Nugroho, A.E., Syamsul, E.S., Andrie, M., Warditiani, K., Lukitaningsih, E., Pramono, S., 2011, The Antidiabetics of Purified Extract of Andrographis paniculata (Burn.f.)Ness and its Active Compound Andrographolide in High Fructose-Fat Fed Rats. Laporan penelitian hibah IMHERE, Fakultas Farmasi UGM, Yogyakarta.

Nurani, L.H., 2008, Diktat Kuliah Farmakognosi, Fakultas Farmasi Universitas Ahmad Dahlan, Yogyakarta. Hal.31.

Rais, I.R, 2012, Ekstraksi Dengan Polaritas Andrografolid dari Andrographis paniculata (Burm.f.) Menggunakan Ekstraktor Soxhlet, Laporan Penelitian, Universitas Ahmad Dahlan, Yogyakarta.

Rais, I.R., 2013, Pengaruh Isolat Andrografolid Terhadap Kadar Glukosa Darah Terkait Histologis Pankreas Tikus Diabetes Mellitus Defisiensi Insulin Serta Kajian Aktivitas $\alpha$-Amilase dan $\alpha$-Glukosidase, , Tesis, Fakultas Farmasi, Universitas Gadjah Mada, Yogyakarta

Selawa, W., Runtuwene, M.R.J., Citraningtyas, G., 2013, Kandungan Flavonoid dan Kapasitas Antioksidan Total Ekstrak Etanol Daun Binahong (Anredera cordifolia (Ten.)Steenis, Jurnal Ilmiah Farmasi Pharmacon, Universitas Sam Ratulangi.
Siswandono, Soekardjo, B., 2000, Kimia Medisinal, Edisi kedua, Airlangga University Press, Surabaya. Hal.3-5.

Soediro, S., 1973, Pemeriksaan zat pahit dalam daun sambiloto (Andrographis paniculata Nees dari Bandung, Jawa). Acta Pharmaceutica.

Sudarsono, Puidjoarinto, A., Gunawan, D., Wahyuono, S., Donatus, I.A., Drajad, M., Wibowo, S., Ngatidjan, 2006, Tumbuhan Obat 1. Pusat Penelitian Obat Tradisional, Universitas Gadjah Mada, Yogyakarta. Hal 25-28.

Sudjadi, 1988, Metode Pemisahan, Kanisius, Yogyakarta.

Sule, Q.U., Ahmed, O.A., Samah, Omar, M.N., 2010, Screening for Antibacterial Activity of Andrographis paniculata Used in Malaysian Folkloric Medicine: A Possible Alternative for the Treatment of Skin Infections. Malay.J.of Med.Sci., Pubmed

Stahl, E., 1985, Analisis Obat dengan Kromatografi dan Mikroskopi, diterjemahkan oleh Kosasih Padmawinata, Penerbit ITB Bandung.

Subramanian, R., Asmawi, M.Z., Sadikun, A., 2008, In vitro alpha-glucosidase and alpha-amylase enzyme inhibitory effects of Andrographis paniculata extract and andrographolide. Acta, J. Biochim Pol.,55(2): 391-398.

Syamsul, E.S., 2012, Uji Aktivitas Antidiabetes, Antihiperlipidemia, dan Antiaterosklerosis Kombinasi Ekstrak Terpurifikasi Herba Sambiloto, (Andrographis paniculata (Burm.f.) Ness) dan Metformin Pada Tikus Diabetes Insulin Tipe 2 Resistensi Insulin, Tesis, Fakultas Farmasi, Universitas Gadjah Mada, Yogyakarta 
Wibudi, A., Kiranadi, B., Manalu, W., Winarto, A., Suyono, S., 2008, The Traditional Plant, Andrographis paniculata (Sambiloto) Exhibits Insulin-Releasing Actions In vitro. Acta Med. Indonesian. Vol.40, (2).
Zang, X.F., and Tan, B.K., 2000, Antihyperglycemic and antioxidant Properties of Andrographis paniculata in Normal and Diabetic Rats. J.Clin.Exp. Pharmacol Physiol. 27 (3): 58-63 